\title{
Assessment of efficacy of promethazine on seizure activity and its interactions with antiepileptic drugs lorazepam and sodium valproate in rats
}

\author{
Vinod Shinde ${ }^{1 *}$, Sandesh Warudkar ${ }^{2}$
}

\author{
${ }^{1}$ Department of Pharmacology, Smt. Kashibai Navale Medical College \& General Hospital, Narhe, Pune, Maharashtra, \\ India \\ ${ }^{2}$ Medical Services, Zydus Research Centre, Ahmedabad, Gujarat, India
}

Received: 13 November 2019

Revised: 28 November 2019

Accepted: 29 November 2019

*Correspondence:

Dr. Vinod Shinde,

Email: vshinde62@gmail.com

Copyright: (c) the author(s), publisher and licensee Medip Academy. This is an open-access article distributed under the terms of the Creative Commons Attribution Non-Commercial License, which permits unrestricted non-commercial use, distribution, and reproduction in any medium, provided the original work is properly cited.

\begin{abstract}
Background: Presently available antiepileptic drugs are effective in controlling seizures in more than half of patients of all epilepsy but use is often limited by adverse effects. H1 receptor antagonists, have a controversial status in patients of epilepsy. Both pro and antiepileptic effect has been documented in various animal studies. Hence, this study was designed to see the effect of promethazine, an $\mathrm{H}_{1}$ antihistaminic drug and its interactions with antiepileptic drugs lorazepam and sodium valproate in rats.

Methods: The effect of promethazine $(10 \mathrm{mg} / \mathrm{kg})$ and its interactions with antiepileptic drugs lorazepam and sodium valproate was assessed by using maximal electroshock seizures (MES) and chemoshock pentylenetetrazol (PTZ) method.

Results: Promethazine along with lorazepam and sodium valproate in subtherapeutic doses exerted significant protection against MES induced seizures whereas no such protection was observed with PTZ method rather the seizure threshold was reduced.

Conclusions: Subtherapeutic doses of promethazine alone and in combination with lorazepam and sodium valproate showed protection against seizures in MES method. However, proconvulsant effect was seen with PTZ method. This shows dual behavior of promethazine on MES and PTZ induced seizures.
\end{abstract}

Keywords: Lorazepam, Maximal electroshock seizures, Pentylenetetrazol, Sodium valproate, Promethazine

\section{INTRODUCTION}

Epilepsy is the disorder is characterised by seizures but not all seizures are due to epilepsy-febrile seizures or drug induced seizures, for example. ${ }^{1}$ The world health organization estimates that around 39 million people worldwide and 7 million in India have epilepsy. ${ }^{2,3}$ Epilepsy is more common in older people. ${ }^{4,5}$ In the developed world, onset of new cases occurs most frequently in babies and the elderly. ${ }^{6}$ In the developing world, onset is more common in older children and young adults, due to differences in the frequency of the underlying causes. ${ }^{7}$ Current antiepileptic drugs are effective in controlling seizures in about $70 \%$ of patients but their use is often limited by adverse effects. Antiepileptic drugs are among the most common classes of drugs responsible for either isolated cutaneous reactions. Antiepileptic hypersensitivity syndrome is a severe dose independent, idiosyncratic reactions to 
aromatic anticonvulsants like phenytoin and carbamazepine that may result in end organ damage. ${ }^{8,9}$

Inflammatory agent histamine plays important role in cutanous adverse drug reactions caused due to drug hypersensitivity. ${ }^{10,11}$ Also histamine has stimulatory effects upon neurons. It also has suppressive ones that protect against the susceptibility to convulsions, drug sensitization, denervation, supersensitivity, ischaemic lesions and stress. ${ }^{12}$ Antihistaminics may play a crucial role in management of cutaneous ADR caused due to antiepileptic drugs. Promethazine, $\mathrm{H}_{1}$ receptor antagonist is an antiallergic and antiemetic drug having an additional centrally acting anticholinergic property. But, there is controversy regarding use of promethazine as an antihistaminic agent in patients of epilepsy. Both pro and antiepileptic effect of promethazine has been documented in various animal studies. ${ }^{13-18}$ Hence the present study was designed to study the effect of promethazine on seizure activity and its interactions with antiepileptic drugs lorazepam and sodium valproate in rats using subtherapeutic doses.

\section{METHODS}

The study protocol was approved by Institutional Animal Ethics Committee (IAEC approval no: 01/2009/ CPCSEA). The study was conducted between January 2010 to May 2012. All the pharmacological experiments were conducted using albino rats $(n=10)$, weighing between 150 and $200 \mathrm{~g}$. The animals were maintained under controlled environmental conditions such as temperature $\left(21 \pm 2^{\circ} \mathrm{C}\right)$, relative humidity $(30-70 \%)$, and photoperiod of $12 / 12 \mathrm{~h}$ period. They were provided with standard commercial pelleted diet and Aquaguard drinking water ad libitum. They were acclimatized for at least 7 days before the start of experiments. Convulsive tests were carried out between 12.00-15.00 hrs.

Drugs used were injections of promethazine, lorazepam and sodium valproate. Drugs were given in the dose of $0.2 \mathrm{ml} / 100$ gm body weight. Total volume did not exceed more than $1.2 \mathrm{ml}$. Drugs were given by intraperitoneal route. Inj. promethazine (Phenargan $25 \mathrm{mg} / \mathrm{ml}, 2 \mathrm{ml}$ amp), inj. sodium valproate (Encorate $100 \mathrm{mg} / \mathrm{ml}, 5 \mathrm{ml}$ vial) and inj. lorazepam (Lopez $2 \mathrm{mg} / \mathrm{ml}, 2 \mathrm{ml} \mathrm{amp}$ ) were used for the study. All drugs except pentylenetetrazol (PTZ) are available in injectable form. PTZ was available in powder form. Dilutions of PTZ were done freshly before experiment. All drugs were given in subtherapeutic doses, which were decided by trial and error method. Experimental design for the study was: ${ }^{19}$

Group I: Control: $0.1 \mathrm{ml} / 100$ gms,

Group II: Promethazine alone,

Group III: Antiepileptic drug alone (lorazepam or sodium valproate),

Group IV: Promethazine + Antiepileptic drugs (lorazepam or sodium valproate).
Methods of convulsive tests selected:

\section{Supramaximal electroshock seizures ${ }^{20}$}

Rats were tested for tonic hind limb extensor phase (TEP) of electroshock seizure with a convulsiometer using current strength of $150 \mathrm{~mA}$ for 0.2 seconds through the ear electrode. ${ }^{21}$ During screening rats not showing typical extensor phase were discarded. For observing interaction of promethazine with antiepileptic drugs 10 rats were pretreated with subtherapeutic dose of promethazine, 10 rats with lorazepam or sodium valproate and another 10 rats with combination of promethazine and antiepileptic drugs (lorazepam or sodium valproate).

\section{Chemically induced seizure $e^{22}$}

PTZ was given intraperitoneally (ip.) in a dose of about $70 \mathrm{mg} / \mathrm{kg}$ producing seizures in $100 \%$ rats without any mortality. Observations were made for 30 minutes for convulsions to occur after injection of PTZ. Rats were divided in group of $10 .^{23}$ Potentiation of PTZ convulsions by promethazine was elucidated further by taking subtherapeutic dose of PTZ with subtherapeutic dose of promethazine. The effect of promethazine in combination with antiepileptic drugs lorazepam and sodium valproate was also compared using PTZ method.

\section{Statistical analysis}

All values are expressed as percentage of animals showing protective effect. Comparison of percentage protection in promethazine, lorazepam, sodium valproate, and promethazine + lorazepam or sodium valproate with control was done by proportion test. ${ }^{19}$ Data was analyzed on STATA statistical software. $\mathrm{P}<0.05$ was considered as statistically significant and $\mathrm{p}<0.01$ as highly significant.

\section{RESULTS}

Effect of promethazine, and antiepileptic drugs lorazepam and sodium valproate alone and in combination against supramaximal electroshock seizures (MES) are shown in Table 1 and 2. It shows that there was $20 \%$ protection with promethazine, lorazepam and sodium valproate alone. While promethazine in combination with lorazepam and sodium valproate showed $90 \%$ and $60 \%$ protection of which initial was highly significant $(\mathrm{p}<0.01)$.

Table 3 shows seizure producing effect of combination of promethazine (fixed dose) with PTZ. It shows that graded doses of PTZ alone at a dose of 30,40 and $50 \mathrm{mg} / \mathrm{kg}$ do not produced convulsions in rats. Convulsions were observed in $40 \%$ of animals at a dose of $60 \mathrm{mg} / \mathrm{kg}$ and in $100 \%$ of animals at a dose of $70 \mathrm{mg} / \mathrm{kg}$ of PTZ without any mortality. Promethazine in a fixed subtherapeutic dose of $10 \mathrm{mg} / \mathrm{kg}$ in combination with graded dose of PTZ showed $70 \%$ convulsions at $30 \mathrm{mg} / \mathrm{kg}$ and $100 \%$ convulsions at a dose of 40, 50, 60, $70 \mathrm{mg} / \mathrm{kg}$ dose of PTZ 
with decreasing order of average time of onset of convulsion and increase in mortality.

Table 1: Effect of promethazine and lorazepam alone and in combination using electroshock MES method in rats.

\begin{tabular}{|c|c|c|c|c|c|}
\hline $\begin{array}{l}\text { S. } \\
\text { no. }\end{array}$ & Drugs & $\begin{array}{l}\text { Dose } \\
(\mathrm{mg} / \mathrm{kg})\end{array}$ & $\begin{array}{l}\text { Number of } \\
\text { animals }\end{array}$ & $\begin{array}{l}\text { Percentage of animals } \\
\text { protected showing } \\
\text { abolition of extensor phase }\end{array}$ & $\mathbf{P}$ value \\
\hline 1 & Control & & 10 & 0 & \\
\hline 2 & Promethazine & 10 & 10 & 20 & 口0.1360 \\
\hline 3 & Lorazepam & 2 & 10 & 20 & $=0.1360$ \\
\hline 4 & $\begin{array}{l}\text { Promethazine } \\
\text { +Lorazepam }\end{array}$ & $10+2$ & 10 & 90 & $\begin{array}{l}\square 0.001^{* *} \\
\square 0.0092^{* *}\end{array}$ \\
\hline
\end{tabular}

-P value of promethazine, lorazepam and prometazine + lorazepam is compared with Control, $\square \mathrm{p}$ value of promethazine + lorazepam is compared with addition of promethazine and lorazepam; * $\mathrm{p}<0.05$ is significant; **p $<0.01$ is highly significant.

Table 2: Effect of promethazine and sodium valproate alone and in combination using electroshock MES method in rats.

\begin{tabular}{|llllll|}
\hline $\begin{array}{l}\text { S. } \\
\text { no. }\end{array}$ & Drugs & $\begin{array}{l}\text { Dose } \\
(\mathbf{m g} / \mathbf{k g})\end{array}$ & $\begin{array}{l}\text { Number of } \\
\text { animals }\end{array}$ & $\begin{array}{l}\text { Percentage of animals } \\
\text { protected showing abolition of } \\
\text { extensor phase }\end{array}$ & P value \\
\hline $\mathbf{1}$ & Control & 10 & 0 & $\mathbf{0}$ \\
\hline $\mathbf{2}$ & Promethazine & 10 & 10 & 20 & $\mathbf{0}$ \\
\hline $\mathbf{3}$ & Sodium Valproate & 75 & 10 & 20 & $\mathbf{0 . 1 3 6 0}$ \\
\hline $\mathbf{4}$ & $\begin{array}{l}\text { Promethazine } \\
\text { +Sodium Valproate }\end{array}$ & $10+75$ & 10 & 60 & $0.0034^{* *}$ \\
$\square 0.3006$
\end{tabular}

- P value of promethazine, sodium valproate and prometazine + sodium valproate is compared with control; $\square p$ value of promethazine + sodium valproate is compared with addition of promethazine and sodium valproate; ${ }^{*} \mathrm{p}<0.05$ is significant; $* * \mathrm{p}<0.01$ is highly significant

Table 3: Seizure producing effect of combination of promethazine (fixed dose) with PTZ.

\begin{tabular}{|llllll|}
\hline $\begin{array}{l}\text { S. } \\
\text { no. }\end{array}$ & $\begin{array}{l}\text { Promethazine } \\
(\mathbf{m g} / \mathrm{kg})\end{array}$ & $\begin{array}{l}\text { PTZ } \\
(\mathbf{m g} / \mathbf{k g})\end{array}$ & $\begin{array}{l}\text { Animals convulsing } \\
(\%)\end{array}$ & $\begin{array}{l}\text { Average time of onset of } \\
\text { convusion (min) }\end{array}$ & Mortality \\
\hline $\mathbf{1}$ & -- & 30 & 0 & & 00 \\
\hline $\mathbf{2}$ & -- & 40 & 0 & & 00 \\
\hline $\mathbf{3}$ & -- & 50 & 0 & 14 & 00 \\
\hline $\mathbf{4}$ & -- & 60 & 40 & 11 & 00 \\
\hline $\mathbf{5}$ & 10 & 70 & 100 & 13.5 & 00 \\
\hline $\mathbf{6}$ & 10 & 30 & 70 & 08 & 00 \\
\hline $\mathbf{7}$ & 10 & 40 & 100 & 8.5 & 02 \\
\hline $\mathbf{8}$ & 10 & 50 & 100 & 5 & 02 \\
\hline $\mathbf{9}$ & 10 & 60 & 100 & 3.1 & 03 \\
\hline $\mathbf{1 0}$ & 10 & 70 & 100 & & 03 \\
\hline
\end{tabular}

Table 4: Effect of promethazine and lorazepam alone and in combination using chemoshock PTZ method in rats.

\begin{tabular}{|lll|lll|}
\hline $\begin{array}{l}\text { S. } \\
\text { no. }\end{array}$ & Drugs & $\begin{array}{l}\text { Dose } \\
(\mathrm{mg} / \mathrm{kg})\end{array}$ & $\begin{array}{l}\text { Number of } \\
\text { animals }\end{array}$ & $\begin{array}{l}\text { Percentage of animals } \\
\text { protected showing abolition of } \\
\text { tonic clonic phase }\end{array}$ & P value \\
\hline $\mathbf{1}$ & Control & 10 & 0 & - \\
\hline $\mathbf{2}$ & Promethazine & 10 & 10 & 0 & $\mathbf{0}$ \\
\hline $\mathbf{3}$ & Lorazepam & 0.5 & 10 & 30 & $\mathbf{0 . 0 6 0 3}$ \\
\hline $\mathbf{4}$ & $\begin{array}{l}\text { Promethazine } \\
\text { +Lorazepam }\end{array}$ & $10+0.5$ & 10 & 30 & $\square .0603$ \\
\hline
\end{tabular}

- $\mathrm{P}$ value of promethazine, lorazepam and prometazine + lorazepam is compared with control; $\square \mathrm{p}$ value of promethazine + lorazepam is compared with addition of promethazine and lorazepam; $* \mathrm{p}<0.05$ is significant; $* * \mathrm{p}<0.01$ is highly significant. 
Table 5: Effect of promethazine and sodium valproate alone and in combination using chemoshock method in rats.

\begin{tabular}{|c|c|c|c|c|c|}
\hline $\begin{array}{l}\text { S. } \\
\text { no. }\end{array}$ & Drugs & $\begin{array}{l}\text { Dose } \\
\text { (mg/kg) }\end{array}$ & $\begin{array}{l}\text { Number of } \\
\text { animals }\end{array}$ & $\begin{array}{l}\text { Percentage of animals protected } \\
\text { showing abolition of tonic clonic } \\
\text { phase }\end{array}$ & P value \\
\hline 1 & Control & & 10 & 0 & \\
\hline 2 & Promethazine & 10 & 10 & 0 & - \\
\hline 3 & Sodium valproate & 50 & 10 & 20 & -0.1360 \\
\hline 4 & $\begin{array}{l}\text { Promethazine } \\
\text { +Sodium valproate }\end{array}$ & $10+50$ & 10 & 20 & $\begin{array}{l}-0.1360 \\
\square 0.1000\end{array}$ \\
\hline
\end{tabular}

-P value of promethazine, sodium valproate and prometazine + sodium valproate is compared with control; $\square$ p value of promethazine + sodium valproate is compared with addition of promethazine and sodium valproate; ${ }^{*} \mathrm{p}<0.05$ is significant; $* * p<0.01$ is highly significant.

Table 4 and 5 shows effect of promethazine, lorazepam and sodium valproate alone and in combination by using chemoshock seizure induced by PTZ. Results show that there was $00 \%, 30 \%$ and $20 \%$ of animals were protected with promethazine, lorazepam and sodium valproate respectively. With combination of promethazine this protection was $30 \%$ and $20 \%$ in lorazepam and sodium valproate group resp. which was not significant $(\mathrm{p}>0.05)$.

\section{DISCUSSION}

The present work investigated the effect of promethazine, a $\mathrm{H} 1$ receptor antagonist, on seizure activity and its interactions with antiepileptic drugs lorazepam and sodium valproate in rats. The results of the present work provided evidence that subtherapeutic doses of promethazine alone and in combination with lorazepam showed significant protection against TEP of electroshock seizures and this combination may have beneficial results in grandmal seizures. In contrast to electroshock method when promethazine $(10 \mathrm{mg} / \mathrm{kg})$ was tested alone and in combination with antiepileptic drugs in chemoshock method, it did not show any protection rather a proconvulsant action was seen, suggesting histamine plays a protective role in the development of convulsions. Hence its use in petitmal or absence seizures cannot be recommended.

The exact underlying mechanisms of such dual behavior of promethazine on MES and PTZ induced seizures are unclear. The reason may be the essential difference between the mechanism of tonic extension and that of clonus. When promethazine was tested by PTZ induced seizures for experimental activity, it significantly reduced threshold for seizures. The possible explainations for proconvulsant activity of promethazine could be (a) Blockade of histamine induced opening of homomultimeric $\mathrm{GABA}_{\mathrm{A}}$ recepors, (b) blockade of $\mathrm{H}_{1}$ receptor mediated reduction of a background $\mathrm{K}^{+}$current in cenral neuron, (c) selective inhibition of brain NaKATPase. $^{24-26}$

Promethazine also has centrally acting antcholinergic properties. It is postulated that acetylcholine plays a role in proconvulsant action of the muscarinic agonist pilocarpine used in experimental models of human epilepsy. It is observed that stimulation of brain muscarinic receptors cause persistent tonic clonic convulsions suggesting enhancement of muscarinic neurotransmission as a mechanism of induction of seizure activity by agents that inhibit neural acetylcholinesterase (e.g. organophosphate inhibitors). ${ }^{27}$

It is well known that GABAergic and glutaminergic mechanisms are directly associated with the seizure activity. ${ }^{28}$ When histamine diffuses away from its synapse to a glutamate synapse containing NMDA receptors, it can act at an allosteric modulatory site called the polyamine site, to alter the actions of glutamate at NMDA receptors. The role of histamine and function of this action are not well clarified. ${ }^{29}$

Further, $\mathrm{H}_{1}$ receptor activation causes excitation in most brain regions (brainstem, thalamus, hypothalamus, cortex, amygdala, striatum) through Gq11 protein and a direct block of a leak potassium conductance or phospholipase inositol triphosphate (IP3) and diacylglycerol (DAG) mediation. IP3 releases calcium ions from internal stores and activates a number of calcium dependent processes, including opening of a cation channel (TRPC) or the stimulation of $\mathrm{Na}^{+}-\mathrm{Ca}^{++}$exchanger (NCX). ${ }^{30}$ Centrally acting anticholinergics like promethazine by blocking $\mathrm{H} 1$ receptors can interfere with functions in these important brain regions.

In our previous study we have also compared subtherapeutic doses of promethazine alone and in combination with diazepam and phenytoin. In that study it was demonstrated that subtherapeutic doses of promethazine alone and in combination with diazepam showed significant protection against TEP of electroshock seizures and this combination may have beneficial results in grandmal seizures ${ }^{31}$

The results of present study are in consistent with the previous study conducted by Tanaka et al who reported anticonvulsant activity of some local anaesthetics, some antihistaminics, spasmolytics, analgesics and some other miscellaneous drugs. ${ }^{18}$ Majority of these drugs caused excitation and convulsions in toxic doses. The toxic 
convulsion was always type of clonic seizure and tonic extension never occurred. Hence, they coined a new term 'antiextensors' in order to avoid contradictory explanation such as "anticonvulsant property" of convulsant drugs.

In the present study it was found that promethazine was capable of preventing tonic extension in MES seizures but when promethazine was tested by PTZ induced seizures for its experimental activity, it significantly reduced threshold for seizures. In combination with antiepileptic drugs, the anticonvulsant activity of promethazine is limited to electroshock seizure and no protection was afforded by these compounds against PTZ convulsions. Rather, it tends to facilitate the clonic seizures of PTZ.

\section{CONCLUSION}

We can extrapolate finding of present study that promethazine reduces seizure threshold in PTZ induced seizures to conclude that the use of promethazine in combination with antiepileptic drugs in petitmal seizures cannot be recommended. Combination of promethazine with lorazepam showed highly significant protection against MES induced seizures. Promethazine in combination with sodium valproate also showed significant protection against MES induced seizures. So these combination are likely to have clinical significance.

\section{Limitations}

- Results of animal study cannot be fully extrapolated to human epilepsy and seizures. It has to be concluded by a clinical study.

- Promethazine has a strong sedative action and hence concurrent use with benzodiazepines is again a limiting factor for clinical use of promethazine in the management of epilepsy.

- Problem of convulsive phenomena creates a degree of background concern about its use.

- More needs to be known about the difference in the mechanism of action of promethazine on MES and PTZ induced seizures which will help to decide the safety of use of promethazine in grandmal and petitmal epilepsy.

\section{ACKNOWLEDGEMENTS}

The help rendered by Mr. Khapre, Laboratory assistant, NKPSIMS \& RC-Nagpur, was duly acknowledged.

Funding: No funding sources

Conflict of interest: None declared

Ethical approval: The study was approved by the Institutional Animal Ethics Committee

\section{REFERENCES}

1. Berg AT, Berkovic SF, Brodie MJ, Buchhalter J, Cross JH, van Emde Boas W, et al. Revised terminology and concepts for organization of seizures and epilepsies: report of the ILAE Commission on Classification and Terminology, 2005-2009. Epilepsia. 2010;51:676-85.

2. Disease GBD, Injury I, Prevalence C. Global, regional, and national incidence, prevalence, and years lived with disability for 310 diseases and injuries, 1990-2015: a systematic analysis for the global burden of disease study 2015. Lancet. 2016;388(10053):1545-602.

3. WHO Media Centre, Fact sheet N0 999, 2009.

4. Brodie MJ, Elder AT, Kwan P. Epilepsy in later life. Lancet Neurol. 2009.8(11):1019-30.

5. Holmes TR, Browne GL. Handbook of epilepsy (4th ed.). Philadelphia: Lippincott Williams \& Wilkins; 2008.

6. Wyllie's treatment of epilepsy: principles and practice (5th ed.). Philadelphia: Wolters Kluwer/Lippincott Williams \& Wilkins. 2010.

7. Newton CR. Epilepsy in poor regions of the world. Lancet. 2012;380(9848):1193-201.

8. Rang HP, Dale MM. Antiepileptic drugs, In: Pharmacology 5th edition, Churchil Livingstone, Elsevier Sciences Limited, Edinburgh; 2003: 550.

9. Schlienger RG, Shear HN. Antiepileptic drug hypersensitivity syndrome. Epilepsia. 1998;39(7):S37.

10. Hennino A, Berard F, Guillot I, Saad N, Rozières A, Nicolas JF. Pathophysiology of urticaria. Clin Rev Allergy Immunol. 2006;30:3-11.

11. Drain KL, Volcheck GW. Preventing and managing drug induced anaphylaxis. Drug Saf. 2001;24:843-53.

12. Tedeschi DH, Benigni JP, Elder CJ. Effects of various phenothiazines on minimal electroshock seizure threshold and spontaneous motor activity of mice. J Pharmacol Experimental Therap. 1958; $123: 35-8$.

13. Kamel C, Ohuch M, Sugimoto Y, Okuma C. Mechanism responsible for epileptogenic activity by first generation $\mathrm{H} 1$ antagonists in rats. Brain Res 2000;887(1):183-6.

14. Scherki R, Hashem A, Frey H. Histamine in brain, its role in regulation of seizure susceptibility. Epilepsy Res. 1991;10:111-8.

15. Saper CB, Chou TC, Scammell TE. The sleep switch: Hypothalamic control of sleep and wakefulness. Trends Neurosci. 2001;24:726-31.

16. Sen P. Histaminergic mechanisms in experimental convulsions. Indian J Exp Biol. 1991;29:375-8.

17. Saxena VC, Bapat SK, Dhawan BN. An experimental evaluation of the anticonvulsant activity of some antihistaminic drugs. J Pharmacol. 1969;19:477-84.

18. Tanaka K, Kawasaki Y. A group of compounds possessing anticonvulsant activity in the maximal electroshock seizure in rats. J Pharmacol. 1957;6:115-21.

19. Dashputra AV, Borkar AS, Hemnani TJ, Badwaik RT. Effect of ketamine on seizure activity and its interactions with antiepileptic drugs in rats. IJMPS. 2012;03(02):1-8. 
20. Huwiler A. Electroshock in mice. In: Vogel HG, editor. Drug Discovery and Evaluation: Pharmacological Assays. 3rd ed, Vol. 1. SpringerVerlag: Berlin, New York; 2008: 692-693.

21. Swinyard EA, Brown WC, Goodman. Comparitive assay of antiepileptic drugs in mice and rats. J Pharmacol Express Ther 1952;106:319.

22. Huwiler A. Pentylenetetrazole (Metrazol) induced convulsions. In: Vogel HG, editor. Drug Discovery and Evaluation: Pharmacological Assays. 3rd ed, Vol. 1. Springer-Verlag: Berlin, New York; 2008: 613-614

23. Richard RK, Everett GM. Analgesics and anticonvulsant properties of 3,5,5 trimethylloxazolidine, 2-4 dione (Tridione). Fed Proc. 1944: 39-44.

24. Saras A, Glosslmann G, Vogt- Elsele AK, Erlkamp KS. Histamine action on vertebrate GABAA receptors. Direct channel gating and potentiation of GABA responses. J Biol Chem. 2008;283(16):1041075 .

25. Sangalli BC. Role of histaminergic neuronal system in the CNS toxicity of the first generation $\mathrm{H} 1$ antagonists. Progress Neurobiol. 1997;52(2):145-57.

26. Hovart A, Momic T, Bunjac A, Petrovic S. Selective Inhibition of brain Na, K- ATPase by drugs. Physiol. 2006;55:325-38.
27. Kai MS, Hirvonen MR. Second messengers in cholinergic induced convulsions and neuronal injury. Toxicol Letters. 1992;64:437-45.

28. Belousov AB, O'hara BF, Denisova JV. Acetylcholine becomes the major excitatory neurotransmitter in the hypothalamus in vitro in the absence of glutamate excitation. $\mathbf{J}$ Neurosci. 2001;21(6):2015-17

29. Stahl SM. Stahl's Essentials Psychopharmacology, 3rd edition, NewYork, NY Cambridge Univerity Press. 2008: 1027-34.

30. Panula P, Nuutinen S. The histaminergic network in the brain: basic organization and role in disease. Nat Rev Neurosci. 2013;14(7):472-87.

31. Warudkar S, Shinde V, Borkar A. Effect of promethazine on seizure activity and its interactions with antiepileptic drugs diazepam and phenytoin in Rats. Int J Basic Clin Pharmacol. 2018;7:1100-4.

Cite this article as: Shinde V, Warudkar S. Assessment of efficacy of promethazine on seizure activity and its interactions with antiepileptic drugs lorazepam and sodium valproate in rats. Int $\mathrm{J}$ Basic Clin Pharmacol 2020;9:42-7. 